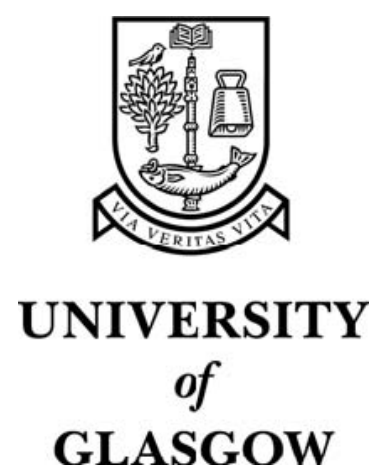

Danbolt, J. and Rees, W. (2002) The valuation of European financial firms. Review of Accounting and Finance 1(1):pp. 5-24.

http://eprints.gla.ac.uk/3687/ 


\title{
The Valuation of European Financial Firms
}

\author{
Jo Danbolt* and William Rees** \\ *University of Glasgow, UK and **Universiteit van Amsterdam, The Netherlands
}

JEL Classification: $\quad$ M41, G12, G20

Keywords: $\quad$ Valuation Models, Financial Institutions

\section{Address for Correspondence:}

Jo Danbolt, Department of Accounting and Finance, University of Glasgow, 65-73 Southpark Avenue, Glasgow G12 8LE, UK. Tel: +44 (0) 141330 6289; Fax: +44 (0) 141330 4442; E-mail: j.danbolt@accfin.gla.ac.uk

William Rees, Amsterdam Graduate Business School, Universiteit van Amsterdam, Roetersstraat 11, 1018 WB Amsterdam, The Netherlands.

\section{Acknowledgements:}

We are grateful to Ahmed Riahi-Belkaoui (the editor), Peter Walton, two anonymous referees, and the participants at a research seminar at University of Cadiz, for helpful comments on a previous version of this paper. The responsibility for any errors rests fully with the authors. 


\title{
The Valuation of European Financial Firms
}

\begin{abstract}
We extend the recent literature concerning accounting based valuation models to investigate financial firms from six European countries with substantial financial sectors: France, Germany, Italy, Netherlands, Switzerland and the UK. Not only are these crucial industries worthy of study in their own right, but unusual accounting practices, and inter-country differences in those accounting practices, provide valuable insights into the accounting-value relationship. Our sample consists of 7,714 financial firm/years observations from 1,140 companies drawn from 1989-2000. Sub-samples include 1,309 firm/years for banks, 650 for insurance companies, 1,705 for real estate firms, and 3,239 for investment companies. In most countries we find that the valuation models work as well or better in explaining cross-sectional variations in the market-to-book ratio for financial firms as they do for industrial and commercial firms in the same countries, although Switzerland is an exception to this generalization. As expected, the results are sensitive to industrial differences, accounting regulation and accounting practices. In particular, marking assets to market value reduces the relevance of earnings figures and increases that of equity.
\end{abstract}




\section{The Valuation of European Financial Firms}

\section{Introduction}

We investigate the relationship between accounting variables and valuation for financial firms drawn from six European countries with substantial financial sectors: France, Germany, Italy, Netherlands, Switzerland and the UK. Financial firms have largely been ignored in previous studies of this type, despite being a substantial part of the market. Indeed, financial firms on average make up almost one quarter of the listed firms in the markets examined.

Furthermore, the accounting practices for financial firms reveal a number of interesting developments rarely found elsewhere. In a paper of this length we cannot start to do justice to a review of the accounting for financial firms in Europe. It is also unclear whether a review of accounting regulations is informative regarding the accounting practices employed as European regulations (i) often allow considerable scope and (ii) they are not always followed closely. To illustrate, Hoogendoorn (1999) notes that in the Netherlands investment firms can value investments at historic cost or market value and 'recognize all changes, realized and unrealized, in income...(or) only realized gains in income, or even to recognize all realized and unrealized changes in market value in a separate reserve as part of shareholders' equity' (p753). Scheid and Walton (1999) note that for France, 'the existence of (a) regulation does not necessarily mean that companies comply with it. Sometimes there are no penalties..., no machinery to police compliance... and tacit agreement that some regulations will simply be ignored' (p304). They also report that in 1992, of 100 listed firms, 36 used non-French, usually either IASC or US, GAAP for their consolidated statements. According to Raffounier (1999) much the same applies to Swiss firms. They claim that about $40 \%$ of firms use international GAAP for their consolidated group accounts (p1337). So, for example, where accounting regulations for the accounts of legal entities expressly forbid the revaluation of property, as in Germany or Switzerland, or discourage it, as in France or Italy, holding companies may well be able to incorporate revaluations in the consolidated accounts of the group as these may be prepared using international or US GAAP. 
However, our review of these practices suggests that there are two crucial dimensions of differences (Alexander and Archer, 1999; Price Waterhouse, 1995). Firstly, there is considerable difference in the propensity to revalue investment assets - primarily investment properties and financial investments. Thus, in the Netherlands and the UK, it would be normal for these assets to be marked to market, whereas in Germany and Switzerland it would be expressly forbidden for individual company accounts and consequently rare in consolidated financial statements. Even where assets are revalued, the unrealized profits may not be recognized until realized - and in many instances not even then. The second characteristic of particular importance is the commitment of the accounting procedures to report the economic substance of the year's transactions. Again the Netherlands and the UK, which exhibit a strong shareholder orientation, can be differentiated from Germany and Switzerland where the stakeholder approach and the influence of taxation has lead to considerable smoothing and suppression of earnings. Raffournier (1999) notes that 'in Switzerland, the creation of hidden reserves is expressly allowed by law' (p1349) and refers to evidence that suggests that 'reported income represents less than 25\% of estimated real earnings' (p1350). Although Seckler (1999) is less blunt about the German accounting system, it is telling that Germany has the most developed and formalized system that we are aware of for comprehensively re-stating reported earnings to derive earnings estimates that are of value to investors (Harris, Lang and Möller, 1994). Our understanding is that France is moving from a situation close to that of Germany and Switzerland towards that represented by the Netherlands and the UK. For example, Scheid and Walton (1999, p290) note that in France 'the days of profit smoothing, lack of consistency of accounting policies and minimal disclosures are largely a thing of the past'. While Italy may also be slowly moving in this direction, Zambon (1999, p630) notes that Italian accounting '...will probably continue to be inspired for a certain period by ... issues of fiscal consequences, conservatism, and secrecy'.

Before going further, it may be useful to illustrate that the impact of the accounting choices available is substantial. For 1999, the British property company Land Securities plc, which was selected at random for illustrative purposes, reported profits of $£ 216.4 \mathrm{~m}$. As these included only realized gains that had not previously been accounted for as unrealized gains, historic cost profit 
would have been $£ 75.1 \mathrm{~m}$ higher than that reported. Full mark to market accounting would have increase profits by $£ 332.9 \mathrm{~m}$. The value of property on the balance sheet, at $£ 6,910.3 \mathrm{~m}$, included $£ 3,286.5 \mathrm{~m}$ representing the revaluation reserves. The accounting choices facing financial firms in Europe are not trivial.

We firstly estimate a model of market value with earnings and book value of equity as the explanatory variables. In this model, the sensitivity of value to both earnings and book value is permitted to vary if earnings are negative (Rees, 1999). A second model also differentiates between that proportion of earnings distributed as dividends and that retained. Following Rees (1997) and Fama and French (1998), this is interpreted as a partitioning of earnings into relatively permanent and relatively transitory components. The models are deflated by book value to mitigate heteroscedasticity.

We find that the models explanatory power for our sample of financial firms is generally higher than that of similar models estimated using industrial and commercial firms (e.g. GarcíaBorbolla, Larrán and Rees, 2001). The clearest, and perhaps unsurprising, exception concerns the Swiss sample where the earnings based model has negligible explanatory power, despite quite typical performance of similar models on non-financial Swiss firms (García-Borbolla et al., 2001).

We also find significant differences in the estimated models across countries and industries. Clear and extreme examples are Italian insurance firms where the estimated equity and earnings multiples are 0.118 and 22.155 respectively (37.9\% explanatory power) and the Dutch real estate sample where the equivalents are 0.961 and 0.194 (76.0\% explanatory power). These results are to be expected where Italian insurance firms report very conservative earnings, whereas Dutch real estate firms are assiduous in marking their balance sheet assets to market.

Section 2 briefly reviews previous papers that have touched on the valuation of financial companies. The research methods adopted are explained in section 3 , while the data is described in section 4. The results follow in section 5 , while the conclusions are contained in section 6 .

\section{Prior Research}

Prior studies on the relationship between accounting variables and firm valuation have 
tended to exclude non-industrial firms. The reasons for excluding financial firms, property companies or investment trusts are not always clearly stated, although Rees (1997, p. 1123) argue that 'This restriction is conventional as the relationship between value and accounting numbers is thought to be very different for financial firms as opposed to those included in the sample'. Thus there is limited prior evidence as to whether Ohlson-type valuation models are effective in explaining the cross-sectional variation in the market-to-book ratio (and produce coefficients which are not inconsistent with theoretical predictions) for financial firms (Ohlson, 1995).

However, Barth, Beaver and Wolfson (1990) examined models of the level and change in US banks valuation over the period from 1969-1987, splitting earnings into earning before securities transaction gains or losses and the securities trading gains and losses (STGL) themselves. They reported that the slope coefficient on earnings was positive and significant and that the coefficient on STGL fluctuated and was insignificantly different from zero. After 1973 the slope coefficient on earnings was approximately 5 (it was considerably higher before then) and the explanatory power averaged 48 percent.

In a complimentary study, Warfield and Linsmeier (1992) examined the market reaction to the disclosure of STGL elements of quarterly accounts. In their analysis of 143 results of US firms published during 1980-1985, they found that market reactions were related to the expected effect on taxes in the first three quarters of the year, but not in the fourth. Their rationalization of the fourth quarter results was consistent with Barth, Beaver and Landsmand's (1992) explanation that earnings management effects contaminate the value relevant information in STGL.

Barth, Landsman and Walhen (1995) extended the results from Barth et al. (1990) by including measures of the volatility of earnings per share measured using historic cost and alternatively using fair value accounting for investment securities. The 1,377 cases for US banks were drawn from the years 1976-1990. They found that, using undeflated per share regressions, the fair value calculation of volatility was dominated by the historic cost version. They also segment income into pre-interest income and interest itself and in general interest income was more highly valued than other income, and in a way that was consistent with interest rates. 
Vincent (1999) analyzed the relationship between accounting variables and share returns for a sample of 138 US real estate investment trusts over the period 1994-1996. Earnings per share, funds from operations, cash from operations and earnings before interest, tax, depreciation and amortization were all value relevant, although 'Only EPS provides evidence of greater relative information content' (p100).

Gordon and Vincent (2000) analyzed the valuation of property companies in Hong Kong, UK and US during 1994-1997. They concluded 'that property companies ... are valued similarly despite differences in accounting practices and required financial disclosures' (p25). However, while the level of share prices were significantly related to both net income and book value on a univariate basis in all three countries, net income was no longer significant for the UK if book value was simultaneously included in the regression. Thus, 'book value is valuation sufficient for UK property companies' (p24). On the other hand, they found net income to be valuation sufficient for Hong Kong property firms. These differences were somewhat surprising, given that investment property assets are revalued annually in both Hong Kong and the UK.

Thus, prior research indicates that reported accounting earnings are value relevant for banks and real estate companies, at least in the Hong Kong, UK and US. In this study, we extend the analysis to six European countries with substantial financial sectors, and to other categories of financial firms. While Gordon and Vincent (2000) found investors to value companies consistently across jurisdictions, other studies have shown significant differences between countries in the value relevance of accounting numbers - albeit for industrial and commercial firms. Bartov, Goldberg and Kim (2001) reported that earnings were superior to cash flows in explaining share returns in the US, UK and Canada (where financial reporting is driven by investor requirements and unencumbered by tax requirements), while the reverse was the case for Japan and Germany. In addition, the explanatory power of both earnings and cash flows were substantially lower in Japan and Germany than in the Anglo-Saxon countries. Similarly, in an analysis of industrial companies in 21 countries during 1991-1997, Hung (2001) found accrual accounting (as compared to cash accounting) had a negative impact on the value relevance of accounting measures in countries with weak investor protection, but not in countries with strong protection of shareholder rights. Alford, Jones, Leftwich 
and Zmijewski (1993) and Ali and Hwang (2000) also found the value relevance of accounting numbers to vary significantly between financial systems. In particular, value relevance was found to be lower in: (i) bank oriented than in market oriented economies, (ii) in markets where governments rather than private sector bodies were involved in setting accounting standards, (iii) for Continental model than for British-American model countries, and (iv) in countries where tax rules significantly influence financial accounting measurements. The comprehensiveness of accounting standards vary significantly between countries (La Porta, Lopez-De-Silanes, Shleifer and Vishny, 1998), and dividend payout ratios tend to be higher in common than in civil law countries and in countries with high as compared to low investor protection (La Porta et al., 1997, 2000). This may have an impact on the value relevance of accounting numbers, in particular on the incremental explanatory power on dividends. Indeed, La Porta et al. (2000, p27) argued that '...dividend policies of firms may convey information to some investors'.

Our analysis is based on six European countries, with substantial heterogeneity with regard to their accounting and legal systems, as summarized in Table 1. These differences, as well as prior empirical evidence based on non-financial firms, suggest that the valuation models we estimate may vary across regimes.

\section{Table 1 about here}

\section{Research Methods}

Our analysis is based on the following model (Rees, 1999):

$$
p r_{t}=e q_{t}\left(1-\frac{\hat{r} \cdot w}{\hat{r}-\hat{g}}\right)+n i t\left(\frac{1+\hat{g}}{\hat{r}-\hat{g}}\right) w
$$

where $p r_{t}$ is the price per share at time $t, n i_{t}$ is clean surplus net income, $e q_{t}$ is book value of equity and $r$ and $g$ are the expected constant values (expectations denoted $\wedge$ ) for the cost of capital and the growth rate of book value and earnings. $w$ indicates the relative weight (between one and zero) placed on current earnings, as opposed to current equity, as indicators of normal base level earnings from which growth in earnings is predicted. The firm subscripts are understood. The model is based on the well-known transformation of the dividend discount model to an accounting based 
valuation model (e.g., Ohlson, 1995) ${ }^{1}$. As an illustrative computation of the coefficients that could be expected from the empirical analysis, let us assume a $12 \%$ cost of capital and a growth rate of $5 \%$. If $w$ is one, the coefficient on equity would be -0.71 and on net income would be +15 . However, were $w$ to be 0.5 then the equity coefficient would be +0.14 and the net income coefficient +7.5 . Results from previous studies, all based on non-financial firms, including Collins, Maydew and Weiss (1997) for the US, Harris et al. (1994) for Germany, Joos and Lang (1994) for Germany, France and the UK and Rees (1997) for the UK, imply the $w$ is somewhat less than one. In all cases the coefficient on net income is less than +15 implied above and the coefficient on equity is positive, as is the intercept term.

The hypotheses are tested using the following model:

$$
\frac{p r_{i t}}{e q_{i t}}=\alpha_{0} \frac{e q_{i t}}{e q_{i t}}+\alpha_{1} \frac{n i_{i t}}{e q_{i t}}+\alpha_{2} D_{i t}+\alpha_{3} \frac{D \cdot n i_{i t}}{e q_{i t}}+\left(\alpha_{4} \frac{d v_{i t}}{e q_{i t}}\right)+\varepsilon_{i t}
$$

where $D_{i t}$ is a dummy variable taking the value 1 where net income is negative, $D . n i_{i t}$ an interactive term between net income and the negative earnings dummy variable ${ }^{2}$, and $d v_{i t}$ is the ordinary dividends for firm $i$ and year $t$. The model is initially estimated with $\alpha 4$ set to zero ${ }^{3}$. The rational is as follows: $\alpha 0$ and $\alpha 1$ estimate the coefficients reflecting growth, cost of capital and the weighting parameter, $\omega$, for cases where earnings are positive; and the dummy variable and interaction terms allow the weighting parameter to vary for cases that have negative earnings. The assumption is that earnings will have approximately a zero weight $(\alpha 1 \approx-\alpha 3)$ when negative, and the weight on equity will increase correspondingly. The inclusion of the dividend variable can be justified on the basis of previous empirical evidence (Rees 1997, Fama and French 1998), but also has theoretical underpinning. If we view distributed earnings as being relatively permanent and undistributed earnings as relatively transitory, then the inclusion of the dividend variable allows the model to differentiate between the weight on permanent and transitory earnings.

The ability of reported earnings to explain cross-sectional variations in share prices can be expected to vary significantly across our sample of European financial firms. We expect earnings to have greatest value relevance in the shareholder oriented regimes - the Netherlands and the UK, and 
we expect it to have least relevance in the stakeholder regimes, most notably Germany and Switzerland, where earnings is subject to smoothing and hidden reserves. In those industries where the revaluation of investment assets is common, such as real estate and investment, we anticipate greater relevance for equity and less for earnings. This is not only because the computation of earnings in such cases can be idiosyncratic, but also because earnings derived from investing in assets traded in efficient markets should have low permanence in comparison to earnings from service industries such as banking and insurance. Finally, we expect to improve our estimation of the influence of earnings by the partition of earnings into retained and distributed portions, and this improvement should be more noticeable where earnings was ineffectual prior to the partitioning.

\section{Data}

An initial sample of 14,057 firm/years for financial companies throughout Europe was obtained from the Company Analysis database. However, a more refined analysis of industrial classifications based on SIC codes, indicated that 1,374 of these firm/years were not definitively financial firms. Missing data further reduced the sample to 9,700 cases ${ }^{4}$. Eliminating countries without at least 400 firm/year observations ${ }^{5}$, and trimming outliers ${ }^{6}$, further reduced the sample to 7,714 financial firm/year observations from a total of 1,140 different companies. Six countries have sufficiently large financial sectors to be included in the analysis: France, Germany, Italy, Netherlands, Switzerland and the UK. In addition to the analysis based on all financial firms, we also analyze those financial industry sub-groups where country specific samples of more than 100 firm/years were available. A full breakdown of the sample composition is contained in Table 2.

\section{Table 2 about here}

The analysis incorporates the following variables:

$\mathrm{pr}_{\mathrm{it}} / \mathrm{eq}_{\mathrm{it}} \quad$ Market-to-Book Ratio, where $\mathrm{pr}_{\mathrm{it}}$ refers to firm i's price per share for ordinary equity at the accounting year end $t^{7}$, and eq it to firm i's book value of equity per share at year end t defined as all equity reserves, and ordinary share capital, but excluding non-ordinary equity such as preference shares, 
$\mathrm{ni}_{\mathrm{it}} / \mathrm{eq}_{\mathrm{it}} \quad$ Net Income to Book Equity, where $\mathrm{ni}_{\mathrm{it}}$ refers to firm i's earnings per share for year $\mathrm{t}$ defined as earned for ordinary after interest charges, extraordinary items and taxation,

$\mathrm{D}_{\mathrm{it}} \quad$ Negative Net Income Dummy, taking the value 1 where $\mathrm{ni}_{\mathrm{it}} / \mathrm{eq}_{\mathrm{it}}$ is negative,

D.ni ${ }_{i t} / \mathrm{eq}_{\mathrm{it}}$ Negative Net Income Interaction. This is an interactive term, combining the negative net income dummy variable with the net income variable, and

$\mathrm{dv}_{\mathrm{it}} / \mathrm{eq}_{\mathrm{it}} \quad$ Ordinary Dividends to Book Equity, where $\mathrm{dv}_{\mathrm{it}}$ refers to firm i's ordinary dividends per share for year $\mathrm{t}$.

Descriptive statistics for the test variables are presented in Table 3. A brief review shows that mean (median) market to book varies from 3.240 (2.219) for Germany to 1.170 (0.959) and 1.195 (0.864) for France and the UK. Certainly the apparent balance sheet conservatism in Germany and optimism in the UK is consistent with expectations and previous evidence about conservative accounting in Europe, although it is surprising to see France in a similar position to the UK (Joos and Lang, 1994). However, the income statement conservatism, indicated by the price-to-earnings ratio, is most apparent in Germany where mean $\mathrm{P} / \mathrm{E}$ is 41.22 , followed by Italy (P/E 32.13), France (P/E 24.02) and the UK (P/E 22.08), whereas Switzerland (P/E 16.93) and the Netherlands (P/E 15.78) report the lowest mean price-to-earnings ratios ${ }^{8}$. Previous studies of industrial and commercial firms have usually indicated that the UK is expected to be one of the least conservative regimes (Joos and Lang, 1994). Further investigation reveals that this aberration is largely driven by the UK investment companies (P/E 33.46) and to a lesser extent by the real estate firms (P/E 21.05). In the UK, only a portion of conventional historic cost profit is passed through the income statement when marking to market is used for investment assets.

\section{Table 3 about here}

The mean of the negative income dummy reveals the incidence of negative earnings in each country. France, Italy and the UK all have negative income in more than $10 \%$ of the cases, whereas at the other extreme German firms report negative income less than $5 \%$ of the time - despite having the lowest mean earnings when standardized by price. This is consistent with prior evidence that German firms tend to smooth earnings whereas French and especially British firms are eager to incorporate bad news into transient losses (Giner and Rees, 2001). 
Finally, the mean dividend yield can be calculated and this is broadly consistent with expectations. France, the Netherlands, and to a lesser extent the UK, pay out high yields and, at the other end of the spectrum, German firms pay the lowest. Again the many real estate and investment firms in the British sample reduce the average dividend yield.

\section{Results}

Table 4 contains the results of the model estimated pooled across all firms in each country ${ }^{9}$. These should be viewed with some caution as the sample for each country is made up from different industries with very different accounting practices and economic circumstances. However, much the same can be said for the many valuation models applied to industrial and commercial samples, and the results included in table 4 do allow us to conclude on the general applicability of the valuation model, the relative importance of equity and income, and the influence of dividends in the model. The most startling result is the comparative failure of the first model using the Swiss sample, which has only trivial explanatory power. Estimates from a similar model using a sample of industrial and commercial firms drawn from a comparable time period revealed quite normal performance for the Swiss sample with an $\mathrm{R}^{2}$ of $25.1 \%$ (García-Borbolla et al., 2001). It does seem that the reported income of Swiss financial firms is particularly irrelevant to value. In the other cases the models have explanatory power ranging from $13.9 \%$ (France) to $58.4 \%$ (the UK). In three instances (Germany, Italy and the UK) the explanatory power is significantly greater than for industrial and commercial firms, whilst for two (France and the Netherlands) there is a noticeable decline. (García-Borbolla et al., 2001). The explanatory power is broadly consistent with our predictions, although the countries expected to be intermediate, France and Italy, fare somewhat worse in the first case, and better in the second, than expected. This is partly explained by difference in industrial composition of the samples, which are discussed later. Even so, the Netherlands and the UK are in the top three by explanatory power and Germany and Switzerland are in the bottom three - as expected.

\section{Table 4 about here}

The estimated coefficients are normally within the broad range expected. The results for France are typical. The equity coefficient is 0.7316 , between 0 and 1 is normal, and the earnings 
coefficient is 5.4885 , and for this variable between 4 and 10 is quite usual. The negative income dummy is positive (0.0729), but insignificantly different from zero, and the interaction term is approximately equal but opposite to the income coefficient (-6.0410). This is entirely consistent with the underlying model where we assume that equity takes some weight in predicting earnings $(\omega<1)$, negative earnings are more or less irrelevant, so that when earnings are negative equity takes greater weight $(\omega \approx 0)$.

The results for three countries fail to fit with this template. The clearest case is Switzerland where earnings have virtually no explanatory power but the coefficient for equity is 1.2903 . Book to market and price to earnings ratios for Switzerland are not abnormal, so it must be assumed that the high equity coefficient is due to the poor value relevance of earnings - i.e. $\omega \approx 0$ whether earnings are positive or negative. The opposite seems to be demonstrated by the Italian results where the earnings coefficient is considerably higher than normal (16.4480) and the equity coefficient is lower (0.2241). This is consistent with high permanence of earnings ( $\omega$ close to 1 ) and with $\omega \approx 0$ when earnings are negative. It is pertinent that for Italy the high earnings coefficient is exacerbated by the low reported earnings figure - the price to earnings ratio is the second highest after Germany. Finally, the German case stands out. Here the equity coefficient is substantially greater than one (1.8393), but this does not appear to be simply because $\omega$ is significantly less than one as the earnings coefficient is, at 15.9930, the second highest after Italy. The explanation here would seem to be down to the innate conservatism of German accounting numbers. Mean market to book for the German sample is over twice that of any other country in our sample and price to earnings is approximately twice the average for other countries (except for Italy which reports 32.13). Thus we would seem to have high coefficients on the German independent variables because we have low values for the independent variables.

In each case the country model is replicated with the addition of a dividends variable. As discussed earlier, we follow Rees (1997) and Fama and French (1998) as viewing this as an indicator of permanent earnings. As would be expected, the value of undistributed (less permanent) earnings decline in comparison with the estimate from the previous equation where distributed and 
undistributed earnings are not differentiated. As the predictive power of earnings is improved, the coefficient on equity declines, and the explanatory power of the model increases - substantially so for the French, Dutch, Swiss and British samples.

In tables 5, 6, 7 and 8 we report the model results for industry sub-samples where the sample of firm/years is more than 100 cases. Caution should be exercised when interpreting these results, as these are small samples that have been pooled over cross-sections and time-series. In the interest of brevity only those cases that add to the insights from table 4 are commented on.

In table 4 the results for the banking industry are presented. These are broadly similar to those of table 3 , suggesting that inter-country differences in table 4 are not caused by industrial differences. These similarities include low equity and high income coefficients in Italy, trivial explanatory power for income in Switzerland and high explanatory power of the model in the UK. However, for the banking industry, the UK sample has higher income and lower equity coefficients than for the full UK sample - suggesting that $\omega$ is closer to 1 for UK banks than for the other firms. Perhaps the clearest difference between the table 4 and table 5 results is for Germany, where the high equity and earnings coefficients of table 4 are not repeated. It is worth noting that dividends are relatively unimportant for the German sample. This is repeated in the following table for the German insurance companies. In both cases negative earnings are rare. It is negative earnings that seem to particularly damage the value relevance of earnings and where dividends are particularly helpful.

\section{Table 5 about here}

The results for insurance firms, reported in table 6, are again largely similar to earlier results. Earnings are important in Italy, insignificant and marginally negative in Switzerland and, as for banks, the British results have higher earnings and lower equity coefficients than does the British full sample. A more abrupt change is the high coefficient on the equity for German firms that will, in part, explain the high equity on the full German sample.

\section{Table 6 about here}

The results for the real estate sector, presented in table 7 , show some substantial differences from the full sample results in table 4. It is here that we first come upon the high earnings and equity coefficients for the German sample, which, we have argued, must be consistent with extreme 
conservatism. The Dutch sample results are curious. The equity coefficient is now close to one and earnings are insignificant - and this would be entirely consistent with marking to market. However, we are unable to explain the high coefficient on negative earnings and the perverse and significant coefficient on the negative income dummy. We suspect that the revaluation of assets has so successfully modeled value that there is no residual use for earnings. The British result is much akin to the full sample results, but the equity coefficients are higher and the earnings coefficients lower than those revealed for banks and insurance companies. This was expected where marking to market is common, and where the earnings figure has little to do with either economic or historic cost accounting profit. However, we had expected the move to equity based valuation to be more abrupt especially given the prior evidence from Gordon and Vincent (2000).

\section{Table 7 about here}

The final set of results concern the investment companies. For the Netherlands and the UK, marking to market is common. Hence we would expect high values on the equity coefficient, low values on the earnings and high explanatory power. We find that the value of the earnings for France is abnormally low, the equity coefficient for the Netherlands is close to one, and the dividend coefficient is extremely high, and that the explanatory power of the UK model is high. These are consistent with expectations. Again we were surprised that equity was not more clearly dominant for the UK sample. However, in this instance we were able to further sub-divide the sample into (i) investment companies as classified by the Financial Times and (ii) other investment firms which tended to be investment advisers. In the first case we find that the equity variable is very influential and closer to one and that the earnings variable is insignificant. In this instance not only are earnings insignificant but dividends, which we use to augment the earnings estimate, are also insignificant. It would appear that for these firms, as for the Dutch real estate sample, equity works well, and there is no room for earnings - even when supported by dividends.

\section{Table 8 about here}

\section{Conclusion}

We have investigated the relationship between accounting variables and the valuation of 
7,714 cases for financial firms from six European countries with substantial financial sectors: France, Germany, Italy, Netherlands, Spain, Switzerland, and the UK. Our sample of firms is segmented between banks, insurance companies, real estate firms, and investment companies. The first result that accounting based models of market to book work relatively well for financial firms - is somewhat surprising as researchers have avoided applying Ohlson style valuation models to financial firms. The exceptions are the few papers that have shown that valuation models work for banks and real estate companies in the US, the UK and Hong Kong, but we are not aware of papers that have extended the approach further. We also found that the value relevance of earnings was high in the traditional shareholder regimes - the Netherlands and the UK, but we were surprised to find that the Italian sample also exhibited such high explanatory power.

We have also found that for those firms which value their balance sheet assets at market prices (which is more prevalent in the shareholder than in the stakeholder oriented economies) - not surprisingly - the equity element of the model is considerably more influential than the income element. This is particularly true of the real estate firms - except for the German sample where revaluation is relatively rare. For investment companies, earnings remains important, but where investment companies were carefully defined to exclude investment advisers, the equity coefficient is close to one and the earnings are of little significance. Perhaps this is unsurprising as in an efficient market returns in one period are unlikely to have much information content for returns in following periods and, as for real estate firms, the income measures for investment companies are based on curious accounting practices.

Finally, we had expected that dividends would be an effective surrogate for earnings, especially where the earnings appeared to be ineffective. There is some evidence that this is the case and the Swiss results are the clearest example. However, in two instances both earnings and dividends are insignificant. These are the Dutch real estate sample and the British, narrowly defined, investment firms sample. In both cases the equity coefficient is close to one. Our interpretation is that earnings have no role to play: not that it is ineffectually measured. Where assets are accurately marked to market, and where earnings are derived from trading in an efficient market, it is not clear 
that abnormal earnings can be predicted on the basis of past earnings. In which case earnings should be, and are, irrelevant for valuation purposes. 


\section{References}

Alexander, D. and S. Archer (eds) (1999) 'The European Accounting Guide', $3^{\text {rd }}$ edition, Harcourt Brace.

Alford, A., J. Jones, R. Leftwich and M Zmijewski (1993), 'The Relative Informativeness of Accounting Disclosures in Different Countries', Journal of Accounting Research, Vol. 31, Supplement, pp183-223.

Ali, A., and L-S. Hwang (2000), 'Country-Specific Factors Related to Financial Reporting and the Value Relevance of Accounting Data', Journal of Accounting Research, Vol. 38, No. 1, pp121.

Barth, M., W. Beaver and W. Landsman (1992), 'The Market Valuation Implications of Net Periodic Pension Cost Components’, Journal of Accounting \& Economics, Vol. 15, pp27-62.

Barth, M., W. Beaver and M. Wolfson (1990), 'Components of Earnings and the Structure of Bank Share Prices’, Financial Analysts Journal, (May-June), pp53-60.

Barth, M., W. Landsman and J. Walhen (1995), 'Fair Value Accounting: Effects on Banks Earnings Volatility, Regulatory Capital, and Value of Contractual Cash Flows', Journal of Banking and Finance, No. 19, pp577-605.

Bartov, E., S.R. Goldberg and M.S. Kim (2001), 'The Valuation-Relevance of Earnings and Cash Flow: An International Perspective’, Journal of International Financial Management and Accounting, Vol. 12, No. 2, pp103-132.

Collins D., E. Maydew and I. Weiss (1997), 'Changes in the Value Relevance of Earnings and Book Value over the last Forty Years’, Journal of Accounting and Economics, Vol. 24 pp39-67.

Fama, E. and K. French (1998), 'Taxes, Financing Decisions, and Firm Value', Journal of Finance, Vol. 53, No. 3, pp819-843.

Fama, E. and J. MacBeth (1973), 'Risk, Return and Equilibrium: Empirical Tests', Journal of Political Economy, Vol. 71, pp607-636.

García-Borbolla, A., M. Larrán and W. Rees, (2001) 'The Value Relevance of Earnings and Dividends in Europe’. Working Paper, University of Glasgow.

Giner, B. and W. Rees (2001), 'On the Asymmetric Recognition of Good and Bad News in France, Germany and the UK', Journal of Business Finance and Accounting, forthcoming.

Gordon, E.A. and L. Vincent (2000), 'A Comparison of the Equity Valuation of Property Companies in Hong Kong, the United Kingdom and the United States', Unpublished manuscript, University of Chicago/Northwestern University.

Harris, T.S., M. Lang and H.P.Möller (1994), 'The Value Relevance of German Accounting Measures: An Empirical Analysis', Journal of Accounting Research, Vol. 32, No. 2 (Autumn), pp187-209.

Hoogendoorn, M. (1999), 'The Netherlands', in D. Alexander and S. Archer (eds) The European Accounting Guide, $3^{\text {rd }}$ edition, Harcourt Brace, pp693-795. 
Hung, M. (2001) 'Accounting Standards and Value Relevance of Financial Statements: An International Analysis', Journal of Accounting and Economics, Vol. 30, pp401-420.

Joos, P. and M. Lang (1994), 'The Effects of Accounting Diversity: Evidence from the European Union’, Journal of Accounting Research, Vol. 32, Supplement, pp141-175.

La Porta, R., F. Lopez-De-Silanes, A. Shleifer and R.W. Vishny (1997), 'Legal Determinants of External Finance', Journal of Finance, Vol. 52, No. 3, pp1131-1150.

La Porta, R., F. Lopez-De-Silanes, A. Shleifer and R.W. Vishny (1998), 'Law and Finance', Journal of Political Economy, Vol. 106, No. 6, pp1113-1155.

La Porta, R., F. Lopez-De-Silanes, A. Shleifer and R.W. Vishny (2000), 'Agency Problems and Dividend Policies Around the World', Journal of Finance, Vol. 55, No. 1, pp1-33.

Price Waterhouse (1995) 'Financial Reporting - An International Survey'.

Ohlson, J. (1995), 'Earnings, Book Values and Dividends in Equity Valuation', Contemporary Accounting Research, Spring, Vol. 11, No. 2, pp661-687.

Raffounier, B. (1999), 'Switzerland' in D. Alexander and S. Archer (eds) The European Accounting Guide, $3^{\text {rd }}$ edition, Harcourt Brace, pp1331-1397.

Rees, W. (1997), 'The Impact of Dividends, Debt and Investment on Valuation Models', Journal of Business Finance and Accounting, Vol. 24, No. 7\&8, pp111-1140.

Rees, W. (1999) 'Influences on the Value Relevance of Equity and Net Income in the U.K.', Managerial Finance, Vol. 25, No. 12, pp58-65.

Scheid, J-C. and P. Walton, (1999), 'France' in D. Alexander and S. Archer (eds) The European Accounting Guide, $3^{\text {rd }}$ edition, Harcourt Brace, pp289-354.

Seckler, G. (1999) 'Germany’ in D. Alexander and S. Archer (eds) The European Accounting Guide, $3^{\text {rd }}$ edition, Harcourt Brace, pp355-461.

Vincent, L. (1999), 'The Information Content of Funds From Operations (FFO) for Real Estate Investment Trusts (REITs)', Journal of Accounting and Economics, Vol. 26, pp69-104.

Warfield, T. and T. Linsmeier (1992), 'Tax Planning, Earnings Management, and the Differential Information Content of Bank Earnings Components', Accounting Review, Vol. 67, No. 3 (July), pp546-562.

White, H. (1980) 'A Heteroscedastic Consistent Covariance Matrix and a Direct Test for Heteroscedasticity’, Econometrica, Vol. 68, pp721-746.

Zambon, S. (1999) 'Italy' in D. Alexander and S. Archer (eds) The European Accounting Guide, $3^{\text {rd }}$ edition, Harcourt Brace, pp522-669. 
Table 1. Accounting and Legal Environment

The table list core differences in the accounting and legal environments in which our sample firms operate. Source of GAAP indicate whether the source for the accounting standards was the government or whether private sector organizations were also involved; Rating on accounting standards examine the inclusion of 90 items in their annual reports; Revaluation indicate whether revaluation of property and financial assets are legal or common; Financial-tax realignment indicate whether tax rules significantly influence accounting measurements, Law indicates the legal origin of the country; and Anti-director right is a measure of shareholder rights over managers (on a scale from a low of 0 to a high of 6). Adapted from Alexander and Archer (1999), Alford et al. (1993), Ali and Hwang (2000), and La Porta et al. (1997, 1998, 2000).

\begin{tabular}{|c|c|c|c|c|c|c|}
\hline & $\begin{array}{c}\text { Source of } \\
\text { GAAP }\end{array}$ & $\begin{array}{l}\text { Rating of } \\
\text { Accounting } \\
\text { Standards }\end{array}$ & Revaluation & $\begin{array}{c}\text { Financial - } \\
\text { Tax } \\
\text { Alignment }\end{array}$ & Law & $\begin{array}{c}\text { Anti- } \\
\text { Director } \\
\text { Rights }\end{array}$ \\
\hline \multicolumn{7}{|c|}{ Stakeholder economies: } \\
\hline Germany & Govt only & 62 & Prohibited & High & $\begin{array}{c}\text { Civil - } \\
\text { German }\end{array}$ & 1 \\
\hline Switzerland & Govt only & 68 & Prohibited & High & $\begin{array}{c}\text { Civil - } \\
\text { German }\end{array}$ & 2 \\
\hline \multicolumn{7}{|c|}{ Intermediate economies: } \\
\hline Italy & Govt only & 62 & Discouraged & High & $\begin{array}{l}\text { Civil - } \\
\text { French }\end{array}$ & 1 \\
\hline France & Govt only & 69 & Discouraged & High & $\begin{array}{l}\text { Civil - } \\
\text { French }\end{array}$ & 3 \\
\hline \multicolumn{7}{|c|}{ Shareholder economies: } \\
\hline Netherlands & $\begin{array}{l}\text { Govt \& } \\
\text { Private }\end{array}$ & 64 & Common & Low & $\begin{array}{l}\text { Civil - } \\
\text { French }\end{array}$ & 2 \\
\hline UK & $\begin{array}{l}\text { Govt \& } \\
\text { Private }\end{array}$ & 78 & Common & Low & $\begin{array}{c}\text { Common - } \\
\text { English }\end{array}$ & 5 \\
\hline
\end{tabular}


Firms classified by Company Analysis as 'Financial' Incorrect industry classification (firm not financial) Control for missing values ${ }^{4}$ :

Financial year below 350 or above 380 days

Remove countries with small samples (>400 firm/years)

Outlier elimination

Final sample

\begin{tabular}{rr} 
& Firm/years \\
1,374 & \\
2,635 & \\
348 & \\
1,676 & \\
310 & 6,343 \\
\hline & $\mathbf{7 , 7 1 4}$
\end{tabular}

Sample composition - Financials:

\begin{tabular}{lrrrrrr}
\multicolumn{2}{l}{ Country (Companies) } & Banks & $\begin{array}{r}\text { Insurance } \\
\text { Companies }\end{array}$ & $\begin{array}{r}\text { Real } \\
\text { Estate }\end{array}$ & $\begin{array}{r}\text { Investment } \\
\text { Companies }\end{array}$ \\
Germany & $(79)$ & 167 & 136 & 195 & & 547 \\
Switzerland & $(77)$ & 265 & 100 & & & 433 \\
Italy & $(58)$ & 219 & 126 & & & 1,203 \\
France & $(185)$ & 345 & 103 & 400 & 275 & 451 \\
Netherlands & $(56)$ & & & 109 & 199 & $\underline{4,506}$ \\
UK & $\underline{(685)}$ & $\underline{313}$ & $\underline{185}$ & $\underline{1,001}$ & $\underline{2,765}$ \\
Total & $(1,140)$ & 1309 & 650 & 1,705 & 3,239 & \\
\hline
\end{tabular}


Table 3. Descriptive Statistics

The table contains descriptive statistics for the full sample of financial firm/years for each country in the analysis. pr/eq refers to the market to book ratio, ni/eq to the net income scaled by book equity, $\mathrm{D}$ to a negative net income dummy variable, D.ni/eq to the interactive term between this dummy variable and net income scaled by book equity, and dv/eq to the dividend scaled by book equity.

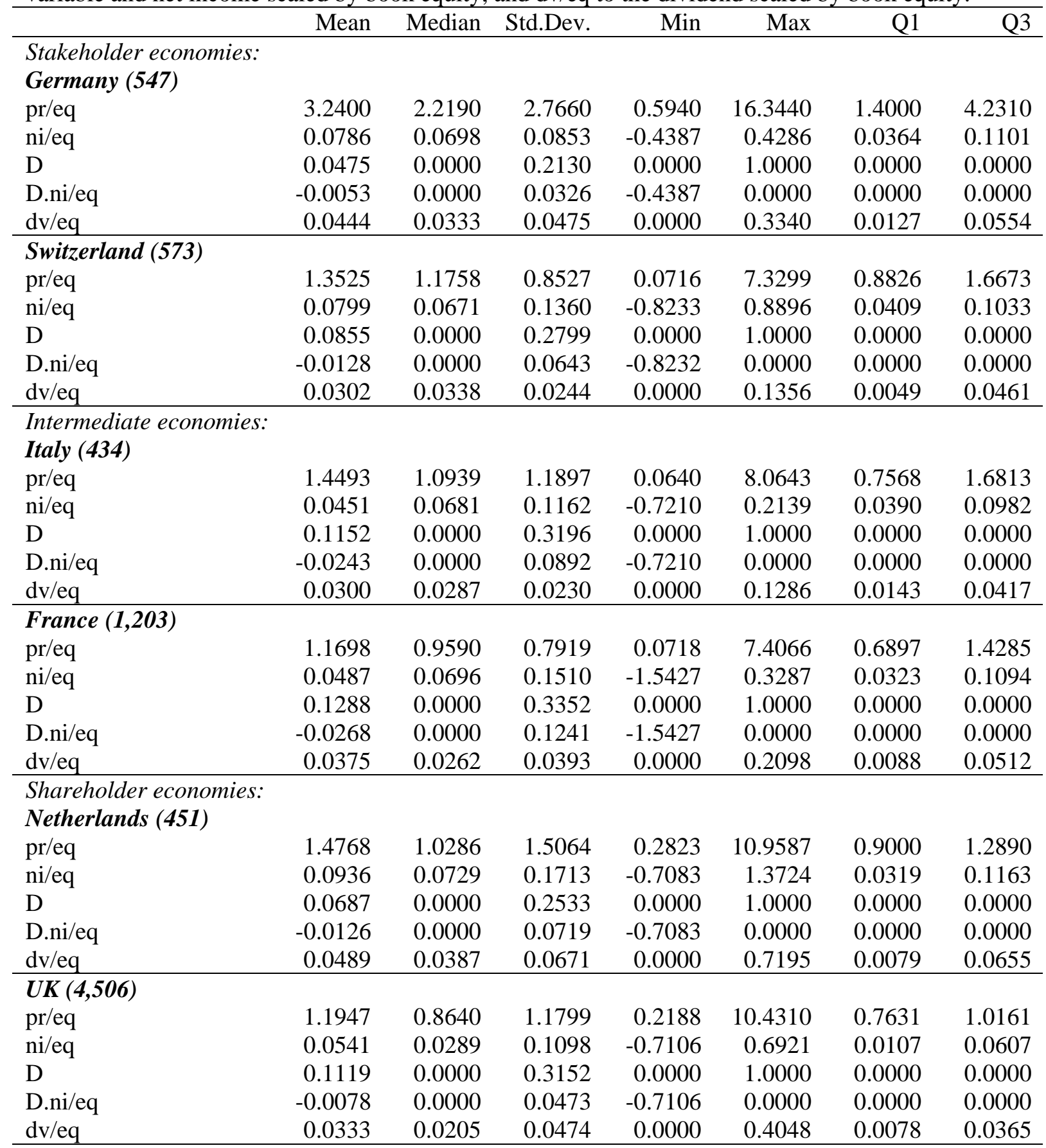


Table 4. Regression Analysis by Country - Financial Firms

The table contains output from OLS regressions of the market to book ratio (pr/eq) on book equity scaled by book equity (eq/eq), net income scaled by book equity (ni/eq), a negative net income dummy variable (D), the interactive term between this dummy variable and net income scaled by book equity (D.ni/eq), and dividends scaled by book equity (dv/eq). Heteroscedasticity-adjusted t-statistics (White, 1980) are reported in brackets.

\begin{tabular}{|c|c|c|c|c|c|c|}
\hline $\begin{array}{l}\text { Country } \\
\text { (Obs.) }\end{array}$ & eq/eq & ni/eq & $\mathrm{D}$ & D.ni/eq & $\mathrm{dv} / \mathrm{eq}$ & $\begin{array}{c}\text { Adj R }{ }^{2} \\
\text { (P-value) }\end{array}$ \\
\hline \multicolumn{7}{|c|}{ Stakeholder economies: } \\
\hline \multirow[t]{2}{*}{$\begin{array}{l}\text { Germany } \\
(547)\end{array}$} & $\begin{array}{l}1.8393 \\
(8.38)\end{array}$ & $\begin{array}{c}15.9930 \\
(6.63)\end{array}$ & $\begin{array}{l}1.0414 \\
(1.34)\end{array}$ & $\begin{array}{c}-17.7990 \\
(-3.57)\end{array}$ & & $\begin{array}{r}16.2 \% \\
(0.000)\end{array}$ \\
\hline & $\begin{array}{l}1.7449 \\
(8.09)\end{array}$ & $\begin{array}{c}12.2330 \\
(4.31)\end{array}$ & $\begin{array}{l}1.1257 \\
(1.45)\end{array}$ & $\begin{array}{c}-14.0630 \\
(-2.70)\end{array}$ & $\begin{array}{l}9.1330 \\
(2.47)\end{array}$ & $\begin{array}{r}17.5 \% \\
(0.000)\end{array}$ \\
\hline \multirow[t]{2}{*}{$\begin{array}{l}\text { Switzerland } \\
\text { (573) }\end{array}$} & $\begin{array}{l}1.2903 \\
(23.75)\end{array}$ & $\begin{array}{l}0.7960 \\
(1.50)\end{array}$ & $\begin{array}{c}-0.0890 \\
(-0.76)\end{array}$ & $\begin{array}{c}-0.4870 \\
(-0.70)\end{array}$ & & $\begin{array}{r}1.0 \% \\
(0.034)\end{array}$ \\
\hline & $\begin{array}{l}0.6848 \\
(10.44)\end{array}$ & $\begin{array}{l}0.9213 \\
(2.34)\end{array}$ & $\begin{array}{c}0.3472 \\
(3.02)\end{array}$ & $\begin{array}{c}-0.8143 \\
(-1.34)\end{array}$ & $\begin{array}{c}18.3460 \\
(10.14)\end{array}$ & $\begin{array}{r}26.3 \% \\
(0.000)\end{array}$ \\
\hline \multicolumn{7}{|c|}{ Intermediate economies: } \\
\hline \multirow[t]{2}{*}{$\begin{array}{l}\text { Italy } \\
(434)\end{array}$} & $\begin{array}{c}0.2241 \\
(1.61)\end{array}$ & $\begin{array}{c}16.4480 \\
(8.05)\end{array}$ & $\begin{array}{c}0.7005 \\
(3.64)\end{array}$ & $\begin{array}{c}-16.5750 \\
(-7.84)\end{array}$ & & $\begin{array}{r}31.0 \% \\
(0.000)\end{array}$ \\
\hline & $\begin{array}{c}0.1700 \\
(1.21)\end{array}$ & $\begin{array}{c}13.5560 \\
(5.96)\end{array}$ & $\begin{array}{l}0.7381 \\
(3.91)\end{array}$ & $\begin{array}{c}-13.7260 \\
(-5.89)\end{array}$ & $\begin{array}{c}8.3060 \\
(2.09)\end{array}$ & $\begin{array}{r}32.0 \% \\
(0.000)\end{array}$ \\
\hline \multirow[t]{2}{*}{$\begin{array}{l}\text { France } \\
(1,203)\end{array}$} & $\begin{array}{l}0.7316 \\
(13.12)\end{array}$ & $\begin{array}{l}5.4885 \\
(7.97)\end{array}$ & $\begin{array}{l}0.0729 \\
(0.88)\end{array}$ & $\begin{array}{c}-6.0410 \\
(-8.21)\end{array}$ & & $\begin{array}{r}13.9 \% \\
(0.000)\end{array}$ \\
\hline & $\begin{array}{l}0.6481 \\
(12.54)\end{array}$ & $\begin{array}{l}2.2431 \\
(3.49)\end{array}$ & $\begin{array}{l}0.1008 \\
(1.26)\end{array}$ & $\begin{array}{l}-3.1041 \\
(-4.12)\end{array}$ & $\begin{array}{l}8.1196 \\
(9.94)\end{array}$ & $\begin{array}{r}24.9 \% \\
(0.000)\end{array}$ \\
\hline \multicolumn{7}{|c|}{ Shareholder economies: } \\
\hline \multirow[t]{2}{*}{$\begin{array}{l}\text { Netherlands } \\
\text { (451) }\end{array}$} & $\begin{array}{l}0.8978 \\
(12.80)\end{array}$ & $\begin{array}{c}5.0852 \\
(7.31)\end{array}$ & $\begin{array}{c}-0.0598 \\
(-0.22)\end{array}$ & $\begin{array}{l}-8.5530 \\
(-3.45)\end{array}$ & & $\begin{array}{r}24.7 \% \\
(0.000)\end{array}$ \\
\hline & $\begin{array}{c}0.7554 \\
(6.04)\end{array}$ & $\begin{array}{l}1.6339 \\
(1.45)\end{array}$ & $\begin{array}{c}0.0514 \\
(0.18)\end{array}$ & $\begin{array}{c}-5.1710 \\
(-1.98)\end{array}$ & $\begin{array}{c}10.2330 \\
(2.05)\end{array}$ & $\begin{array}{r}33.7 \% \\
(0.000)\end{array}$ \\
\hline \multirow[t]{2}{*}{$\begin{array}{l}\text { UK } \\
(4,506)\end{array}$} & $\begin{array}{l}0.5362 \\
(35.20)\end{array}$ & $\begin{array}{l}9.8072 \\
(29.83)\end{array}$ & $\begin{array}{l}0.3668 \\
(10.90)\end{array}$ & $\begin{array}{c}-11.1255 \\
(-18.53)\end{array}$ & & $\begin{array}{r}58.4 \% \\
(0.000)\end{array}$ \\
\hline & $\begin{array}{l}0.4290 \\
(27.23)\end{array}$ & $\begin{array}{l}5.2440 \\
(11.51)\end{array}$ & $\begin{array}{l}0.4071 \\
(13.58)\end{array}$ & $\begin{array}{c}-5.9272 \\
(-9.19)\end{array}$ & $\begin{array}{c}11.7104 \\
(12.83)\end{array}$ & $\begin{array}{r}67.2 \% \\
(0.000)\end{array}$ \\
\hline
\end{tabular}


Table 5. Regression Analysis by Country and Industry - Banks

The table contains output from OLS regressions of the market to book ratio (pr/eq) on book equity scaled by book equity (eq/eq), net income scaled by book equity (ni/eq), a negative net income dummy variable (D), the interactive term between this dummy variable and net income scaled by book equity (D.ni/eq), and dividends scaled by book equity (dv/eq). 'no info' indicates that the negative earnings interaction coefficient could not be estimated as there are insufficient negative income cases in this sample. Heteroscedasticity-adjusted t-statistics (White, 1980) are reported in brackets.

\begin{tabular}{|c|c|c|c|c|c|c|}
\hline $\begin{array}{l}\text { Country } \\
\text { (Obs.) }\end{array}$ & eq/eq & ni/eq & $\mathrm{D}$ & D.ni/eq & $\mathrm{dv} / \mathrm{eq}$ & $\begin{array}{c}\text { Adj R }{ }^{2} \\
\text { (P-value) }\end{array}$ \\
\hline \multicolumn{7}{|c|}{ Stakeholder economies: } \\
\hline \multirow[t]{2}{*}{$\begin{array}{l}\text { Germany } \\
\text { (167) }\end{array}$} & $\begin{array}{l}1.0047 \\
(11.47)\end{array}$ & $\begin{array}{l}6.2320 \\
(4.75)\end{array}$ & $\begin{array}{c}-0.0012 \\
(-0.01)\end{array}$ & no info & & $\begin{array}{r}9.9 \% \\
(0.000)\end{array}$ \\
\hline & $\begin{array}{l}0.9643 \\
(10.94)\end{array}$ & $\begin{array}{c}5.2730 \\
(3.64)\end{array}$ & $\begin{array}{c}0.0384 \\
(0.44)\end{array}$ & no info & $\begin{array}{c}2.7240 \\
(1.42)\end{array}$ & $\begin{array}{r}10.2 \% \\
(0.000)\end{array}$ \\
\hline \multirow[t]{2}{*}{$\begin{array}{l}\text { Switzerland } \\
\text { (265) }\end{array}$} & $\begin{array}{l}1.1779 \\
(12.71)\end{array}$ & $\begin{array}{c}0.9792 \\
(0.84)\end{array}$ & $\begin{array}{l}0.0846 \\
(0.38)\end{array}$ & $\begin{array}{c}-0.8870 \\
(-0.68)\end{array}$ & & $\begin{array}{r}0.1 \% \\
(0.356)\end{array}$ \\
\hline & $\begin{array}{l}0.3798 \\
(3.54)\end{array}$ & $\begin{array}{c}0.5053 \\
(0.95)\end{array}$ & $\begin{array}{l}0.4295 \\
(2.38)\end{array}$ & $\begin{array}{c}-0.9938 \\
(-1.09)\end{array}$ & $\begin{array}{c}24.2980 \\
(9.13)\end{array}$ & $\begin{array}{r}39.5 \% \\
(0.000)\end{array}$ \\
\hline \multicolumn{7}{|c|}{ Intermediate economies: } \\
\hline \multirow[t]{2}{*}{$\begin{array}{l}\text { Italy } \\
(219)\end{array}$} & $\begin{array}{c}-0.0027 \\
(-0.02)\end{array}$ & $\begin{array}{c}17.5100 \\
(7.11)\end{array}$ & $\begin{array}{l}0.6787 \\
(2.75)\end{array}$ & $\begin{array}{c}-17.4190 \\
(-6.90)\end{array}$ & & $\begin{array}{r}49.7 \% \\
(0.000)\end{array}$ \\
\hline & $\begin{array}{l}-0.0441 \\
(-0.27)\end{array}$ & $\begin{array}{c}13.2030 \\
(5.43)\end{array}$ & $\begin{array}{l}0.7201 \\
(2.93)\end{array}$ & $\begin{array}{c}-13.1120 \\
(-5.26)\end{array}$ & $\begin{array}{c}10.6480 \\
(2.28)\end{array}$ & $\begin{array}{r}51.5 \% \\
(0.000)\end{array}$ \\
\hline \multirow[t]{2}{*}{$\begin{array}{l}\text { France } \\
(345)\end{array}$} & $\begin{array}{c}0.6227 \\
(8.66)\end{array}$ & $\begin{array}{c}4.3439 \\
(4.97)\end{array}$ & $\begin{array}{c}-0.0915 \\
(-0.67)\end{array}$ & $\begin{array}{c}-5.3192 \\
(-5.56)\end{array}$ & & $\begin{array}{r}18.1 \% \\
(0.000)\end{array}$ \\
\hline & $\begin{array}{c}0.5894 \\
(9.83)\end{array}$ & $\begin{array}{c}2.6872 \\
(3.21)\end{array}$ & $\begin{array}{c}-0.0844 \\
(-0.65)\end{array}$ & $\begin{array}{c}-3.6965 \\
(-4.03)\end{array}$ & $\begin{array}{c}8.9870 \\
(6.40)\end{array}$ & $\begin{array}{r}26.0 \% \\
(0.000)\end{array}$ \\
\hline \multicolumn{7}{|c|}{ Shareholder economies: } \\
\hline \multirow[t]{2}{*}{$\begin{array}{l}\text { UK } \\
\text { (313) }\end{array}$} & $\begin{array}{c}0.1438 \\
(0.91)\end{array}$ & $\begin{array}{l}12.1758 \\
(10.64)\end{array}$ & $\begin{array}{l}0.8196 \\
(4.27)\end{array}$ & $\begin{array}{l}-12.643 \\
(-10.28)\end{array}$ & & $\begin{array}{r}54.2 \% \\
(0.000)\end{array}$ \\
\hline & $\begin{array}{c}-0.0147 \\
(-0.12)\end{array}$ & $\begin{array}{c}(6.9776 \\
(4.97)\end{array}$ & $\begin{array}{c}0.3434 \\
(1.82)\end{array}$ & $\begin{array}{c}-7.0980 \\
(-4.17)\end{array}$ & $\begin{array}{c}14.9660 \\
(5.21)\end{array}$ & $\begin{array}{r}62.5 \% \\
(0.000)\end{array}$ \\
\hline
\end{tabular}


Table 6. Regression Analysis by Country and Industry - Insurance Companies

The table contains output from OLS regressions of the market to book ratio (pr/eq) on book equity scaled by book equity (eq/eq), net income scaled by book equity (ni/eq), a negative net income dummy variable (D), the interactive term between this dummy variable and net income scaled by book equity (D.ni/eq), and dividends scaled by book equity (dv/eq). 'no info' indicates that the negative earnings interaction coefficient could not be estimated as there are insufficient negative income cases in this sample. Heteroscedasticity-adjusted t-statistics (White, 1980) are reported in brackets.

\begin{tabular}{|c|c|c|c|c|c|c|}
\hline $\begin{array}{l}\text { Country } \\
\text { (Obs.) }\end{array}$ & eq/eq & ni/eq & $\mathrm{D}$ & D.ni/eq & $\mathrm{dv} / \mathrm{eq}$ & $\begin{array}{c}\text { Adj R }^{2} \\
\text { (P-value) }\end{array}$ \\
\hline \multicolumn{7}{|c|}{ Stakeholder economies: } \\
\hline \multirow[t]{2}{*}{$\begin{array}{l}\text { Germany } \\
\text { (136) }\end{array}$} & $\begin{array}{c}2.5831 \\
(9.02)\end{array}$ & $\begin{array}{c}9.4880 \\
(3.56)\end{array}$ & $\begin{array}{l}-0.3580 \\
(-1.02)\end{array}$ & no info & & $\begin{array}{r}6.9 \% \\
(0.003)\end{array}$ \\
\hline & $\begin{array}{c}2.5789 \\
(9.06)\end{array}$ & $\begin{array}{l}7.2970 \\
(2.14)\end{array}$ & $\begin{array}{l}-0.4860 \\
(-1.30)\end{array}$ & no info & $\begin{array}{l}4.8540 \\
(1.29)\end{array}$ & $\begin{array}{r}6.9 \% \\
(0.006)\end{array}$ \\
\hline \multirow[t]{2}{*}{$\begin{array}{l}\text { Switzerland } \\
(100)\end{array}$} & $\begin{array}{l}1.5413 \\
(13.99)\end{array}$ & $\begin{array}{c}-0.6835 \\
(-0.60)\end{array}$ & $\begin{array}{c}-0.0897 \\
(-0.37)\end{array}$ & $\begin{array}{l}0.802 \\
(0.60)\end{array}$ & & $\begin{array}{r}0.0 \% \\
(0.910)\end{array}$ \\
\hline & $\begin{array}{c}0.4598 \\
(3.20)\end{array}$ & $\begin{array}{c}-0.4797 \\
(-1.28)\end{array}$ & $\begin{array}{c}-0.0655 \\
(-0.13)\end{array}$ & $\begin{array}{c}-2.8840 \\
(-1.66)\end{array}$ & $\begin{array}{c}39.6060 \\
(7.27)\end{array}$ & $\begin{array}{r}49.7 \% \\
(0.000)\end{array}$ \\
\hline \multicolumn{7}{|c|}{ Intermediate economies: } \\
\hline \multirow[t]{2}{*}{$\begin{array}{l}\text { Italy } \\
(126)\end{array}$} & $\begin{array}{c}0.1184 \\
(0.48)\end{array}$ & $\begin{array}{c}22.1550 \\
(6.26)\end{array}$ & $\begin{array}{l}0.8651 \\
(2.05)\end{array}$ & $\begin{array}{c}-23.8150 \\
(-6.35)\end{array}$ & & $\begin{array}{r}37.9 \% \\
(0.000)\end{array}$ \\
\hline & $\begin{array}{c}-0.0099 \\
(-0.04)\end{array}$ & $\begin{array}{c}15.5680 \\
(4.48)\end{array}$ & $\begin{array}{l}0.9935 \\
(2.37)\end{array}$ & $\begin{array}{c}-17.2280 \\
(-4.66)\end{array}$ & $\begin{array}{c}22.2170 \\
(2.47)\end{array}$ & $\begin{array}{r}43.2 \% \\
(0.000)\end{array}$ \\
\hline \multirow[t]{2}{*}{$\begin{array}{l}\text { France } \\
\text { (103) }\end{array}$} & $\begin{array}{l}0.8951 \\
(8.37)\end{array}$ & $\begin{array}{l}4.8780 \\
(4.02)\end{array}$ & $\begin{array}{c}-0.0054 \\
(-0.03)\end{array}$ & $\begin{array}{c}-7.8630 \\
(-3.65)\end{array}$ & & $\begin{array}{r}14.5 \% \\
(0.000)\end{array}$ \\
\hline & $\begin{array}{l}0.7227 \\
(7.14)\end{array}$ & $\begin{array}{l}3.5050 \\
(2.65)\end{array}$ & $\begin{array}{l}0.1384 \\
(0.82)\end{array}$ & $\begin{array}{c}-6.5590 \\
(-2.97)\end{array}$ & $\begin{array}{l}9.4400 \\
(3.07)\end{array}$ & $\begin{array}{r}22.9 \% \\
(0.000)\end{array}$ \\
\hline \multicolumn{7}{|c|}{ Shareholder economies: } \\
\hline \multirow[t]{2}{*}{$\begin{array}{l}\text { UK } \\
(185)\end{array}$} & $\begin{array}{c}0.2108 \\
(1.19)\end{array}$ & $\begin{array}{c}13.3750 \\
(9.26)\end{array}$ & $\begin{array}{l}1.0361 \\
(4.64)\end{array}$ & $\begin{array}{c}-14.6130 \\
(-8.43)\end{array}$ & & $\begin{array}{r}48.0 \% \\
(0.000)\end{array}$ \\
\hline & $\begin{array}{c}0.0632 \\
(0.61)\end{array}$ & $\begin{array}{l}4.4625 \\
(4.24)\end{array}$ & $\begin{array}{l}0.1161 \\
(0.71)\end{array}$ & $\begin{array}{l}-4.6020 \\
(-2.94)\end{array}$ & $\begin{array}{c}18.6860 \\
(13.15)\end{array}$ & $\begin{array}{r}77.2 \% \\
(0.000)\end{array}$ \\
\hline
\end{tabular}


Table 7. Regression Analysis by Country and Industry - Real Estate

The table contains output from OLS regressions of the market to book ratio (pr/eq) on book equity scaled by book equity (eq/eq), net income scaled by book equity (ni/eq), a negative net income dummy variable (D), the interactive term between this dummy variable and net income scaled by book equity (D.ni/eq), and dividends scaled by book equity (dv/eq). Heteroscedasticity-adjusted tstatistics (White, 1980) are reported in brackets.

\begin{tabular}{|c|c|c|c|c|c|c|}
\hline $\begin{array}{l}\text { Country } \\
\text { (Obs.) }\end{array}$ & Eq/eq & ni/eq & $\mathrm{D}$ & D.ni/eq & dv/eq & $\begin{array}{c}\text { Adj R }^{2} \\
\text { (P-value) }\end{array}$ \\
\hline \multicolumn{7}{|c|}{ Stakeholder economies: } \\
\hline \multirow[t]{2}{*}{$\begin{array}{l}\text { Germany } \\
\text { (195) }\end{array}$} & $\begin{array}{c}3.2472 \\
(9.26)\end{array}$ & $\begin{array}{c}13.3690 \\
(4.04)\end{array}$ & $\begin{array}{c}0.3860 \\
(0.34)\end{array}$ & $\begin{array}{c}-13.1730 \\
(-1.59)\end{array}$ & & $\begin{array}{r}12.8 \% \\
(0.000)\end{array}$ \\
\hline & $\begin{array}{c}3.0742 \\
(8.89)\end{array}$ & $\begin{array}{l}7.3880 \\
(1.95)\end{array}$ & $\begin{array}{c}0.5590 \\
(0.49)\end{array}$ & $\begin{array}{c}-7.1920 \\
(-0.85)\end{array}$ & $\begin{array}{c}13.7260 \\
(2.90)\end{array}$ & $\begin{array}{r}16.1 \% \\
(0.000)\end{array}$ \\
\hline \multicolumn{7}{|c|}{ Intermediate economies: } \\
\hline \multirow[t]{2}{*}{$\begin{array}{l}\text { France } \\
(400)\end{array}$} & $\begin{array}{l}0.9458 \\
(12.72)\end{array}$ & $\begin{array}{l}5.1739 \\
(5.31)\end{array}$ & $\begin{array}{c}0.0763 \\
(0.52)\end{array}$ & $\begin{array}{c}-5.5880 \\
(-5.34)\end{array}$ & & $\begin{array}{r}9.7 \% \\
(0.000)\end{array}$ \\
\hline & $\begin{array}{c}0.7889 \\
(13.27)\end{array}$ & $\begin{array}{c}0.9100 \\
(1.07)\end{array}$ & $\begin{array}{l}0.1279 \\
(0.92)\end{array}$ & $\begin{array}{c}-1.4760 \\
(-1.61)\end{array}$ & $\begin{array}{l}7.8080 \\
(7.27)\end{array}$ & $\begin{array}{r}16.5 \% \\
(0.000)\end{array}$ \\
\hline \multicolumn{7}{|c|}{ Shareholder economies: } \\
\hline \multirow[t]{2}{*}{$\begin{array}{l}\text { Netherlands } \\
\text { (109) }\end{array}$} & $\begin{array}{l}0.9615 \\
(19.93)\end{array}$ & $\begin{array}{l}0.1941 \\
(0.38)\end{array}$ & $\begin{array}{c}-1.3025 \\
(-2.49)\end{array}$ & $\begin{array}{c}-12.3064 \\
(-8.98)\end{array}$ & & $\begin{array}{r}76.0 \% \\
(0.000)\end{array}$ \\
\hline & $\begin{array}{l}0.9599 \\
(26.54)\end{array}$ & $\begin{array}{l}0.7439 \\
(1.66)\end{array}$ & $\begin{array}{c}-1.3009 \\
(-2.49)\end{array}$ & $\begin{array}{c}-12.8560 \\
(-9.55)\end{array}$ & $\begin{array}{c}0.9200 \\
(1.82)\end{array}$ & $\begin{array}{r}76.1 \% \\
(0.000)\end{array}$ \\
\hline \multirow[t]{2}{*}{$\begin{array}{l}\text { UK } \\
(1,001)\end{array}$} & $\begin{array}{l}0.5355 \\
(13.08)\end{array}$ & $\begin{array}{l}5.8934 \\
(8.31)\end{array}$ & $\begin{array}{c}0.4257 \\
(4.10)\end{array}$ & $\begin{array}{c}-5.5012 \\
(-6.63)\end{array}$ & & $\begin{array}{r}34.4 \% \\
(0.000)\end{array}$ \\
\hline & $\begin{array}{c}0.4056 \\
(9.06)\end{array}$ & $\begin{array}{l}2.9398 \\
(4.11)\end{array}$ & $\begin{array}{c}0.4030 \\
(4.16)\end{array}$ & $\begin{array}{c}-2.8275 \\
(-3.52)\end{array}$ & $\begin{array}{c}11.9975 \\
(4.70)\end{array}$ & $\begin{array}{r}50.2 \% \\
(0.000)\end{array}$ \\
\hline
\end{tabular}


Table 8. Regression Analysis by Country and Industry - Investment Companies

The table contains output from OLS regressions of the market to book ratio (pr/eq) on book equity scaled by book equity (eq/eq), net income scaled by book equity (ni/eq), a negative net income dummy variable (D), the interactive term between this dummy variable and net income scaled by book equity (D.ni/eq), and dividends scaled by book equity (dv/eq). ICs refers to investment companies as classified by the Financial Times, while 'other' refers to other investment firms (predominately investment advisers). Heteroscedasticity-adjusted t-statistics (White, 1980) are reported in brackets.

\begin{tabular}{|c|c|c|c|c|c|c|}
\hline $\begin{array}{l}\text { Country } \\
\text { (Obs.) }\end{array}$ & eq/eq & ni/eq & $\mathrm{D}$ & D.ni/eq & $\mathrm{dv} / \mathrm{eq}$ & $\begin{array}{c}\text { Adj R }^{2} \\
\text { (P-value) }\end{array}$ \\
\hline \multicolumn{7}{|c|}{ Intermediate economies: } \\
\hline \multirow[t]{2}{*}{$\begin{array}{l}\text { France } \\
(275)\end{array}$} & $\begin{array}{c}0.7849 \\
(6.68)\end{array}$ & $\begin{array}{c}2.9896 \\
(1.83)\end{array}$ & $\begin{array}{c}-0.0327 \\
(-0.25)\end{array}$ & $\begin{array}{c}-3.0874 \\
(-1.89)\end{array}$ & & $\begin{array}{r}3.9 \% \\
(0.003)\end{array}$ \\
\hline & $\begin{array}{l}0.6779 \\
(6.11)\end{array}$ & $\begin{array}{c}-1.3523 \\
(-1.15)\end{array}$ & $\begin{array}{c}0.0108 \\
(0.09)\end{array}$ & $\begin{array}{l}1.1830 \\
(1.00)\end{array}$ & $\begin{array}{c}12.6430 \\
(4.62)\end{array}$ & $\begin{array}{r}23.8 \% \\
(0.000)\end{array}$ \\
\hline \multicolumn{7}{|c|}{ Shareholder economies: } \\
\hline \multirow[t]{2}{*}{$\begin{array}{l}\text { Netherlands } \\
\text { (199) }\end{array}$} & $\begin{array}{c}0.9709 \\
(5.74)\end{array}$ & $\begin{array}{l}6.9890 \\
(2.10)\end{array}$ & $\begin{array}{l}-0.0280 \\
(-0.14)\end{array}$ & $\begin{array}{c}-8.0700 \\
(-2.34)\end{array}$ & & $\begin{array}{r}13.7 \% \\
(0.000)\end{array}$ \\
\hline & $\begin{array}{c}0.3529 \\
(4.78)\end{array}$ & $\begin{array}{l}1.4167 \\
(2.98)\end{array}$ & $\begin{array}{c}0.5426 \\
(4.04)\end{array}$ & $\begin{array}{c}-2.6140 \\
(-2.58)\end{array}$ & $\begin{array}{c}31.8630 \\
(11.70)\end{array}$ & $\begin{array}{r}64.3 \% \\
(0.000)\end{array}$ \\
\hline \multirow[t]{2}{*}{$\begin{array}{l}\text { UK } \\
(2,765)\end{array}$} & $\begin{array}{l}0.5839 \\
(26.93)\end{array}$ & $\begin{array}{l}10.5223 \\
(13.58)\end{array}$ & $\begin{array}{l}0.3059 \\
(9.23)\end{array}$ & $\begin{array}{c}-12.7928 \\
(-11.39)\end{array}$ & & $\begin{array}{r}58.3 \% \\
(0.000)\end{array}$ \\
\hline & $\begin{array}{l}0.5285 \\
(22.80)\end{array}$ & $\begin{array}{l}7.6858 \\
(5.74)\end{array}$ & $\begin{array}{c}0.3518 \\
(10.52)\end{array}$ & $\begin{array}{c}-9.7848 \\
(-6.13)\end{array}$ & $\begin{array}{l}6.2119 \\
(2.92)\end{array}$ & $\begin{array}{r}60.2 \% \\
(0.000)\end{array}$ \\
\hline \multirow[t]{2}{*}{$\begin{array}{l}\text { UK - ICs } \\
(2,544)\end{array}$} & $\begin{array}{l}0.8213 \\
(62.29)\end{array}$ & $\begin{array}{l}0.3357 \\
(0.60)\end{array}$ & $\begin{array}{l}0.0332 \\
(1.07)\end{array}$ & $\begin{array}{l}-3.7721 \\
(-2.09)\end{array}$ & & $\begin{array}{r}8.2 \% \\
(0.000)\end{array}$ \\
\hline & $\begin{array}{c}0.8108 \\
(111.87)\end{array}$ & $\begin{array}{c}-0.5758 \\
(-0.42)\end{array}$ & $\begin{array}{l}0.0430 \\
(1.48)\end{array}$ & $\begin{array}{c}-2.9115 \\
(-1.37)\end{array}$ & $\begin{array}{l}1.5630 \\
(1.30)\end{array}$ & $\begin{array}{r}9.06 \\
(0.000)\end{array}$ \\
\hline \multirow[t]{2}{*}{$\begin{array}{l}\text { UK - other } \\
\text { (221) }\end{array}$} & $\begin{array}{l}0.5559 \\
(4.31)\end{array}$ & $\begin{array}{l}12.2694 \\
(11.38)\end{array}$ & $\begin{array}{c}0.9700 \\
(2.31)\end{array}$ & $\begin{array}{c}-12.9480 \\
(-8.89)\end{array}$ & & $\begin{array}{r}59.6 \% \\
(0.000)\end{array}$ \\
\hline & $\begin{array}{l}0.3632 \\
(3.12)\end{array}$ & $\begin{array}{l}5.8150 \\
(3.47)\end{array}$ & $\begin{array}{c}0.5015 \\
(1.40)\end{array}$ & $\begin{array}{c}-7.1710 \\
(-3.82)\end{array}$ & $\begin{array}{c}15.0130 \\
(5.14)\end{array}$ & $\begin{array}{r}67.6 \% \\
(0.000)\end{array}$ \\
\hline
\end{tabular}


${ }^{1}$ The assumptions required to move from value as the present value of expected dividends to equation one above are: that expectations of time series of book value, net income and equity disbursements or increments (usually designated dividends) are governed by the clean surplus relationship - i.e. $e q_{t}=e q_{t-1}+n i_{t}+d v_{t}$; that both the expectations of the required rate of return and the growth rate of book value and net income can be equated to a constant equivalent; that the expected growth of book value and net income are the same; and finally that a current base level for earnings, from which growth is extrapolated, is a weighting of current net income and current book value of equity times the required rate of return.

${ }^{2}$ There may be a theoretical argument for also interacting the negative earnings dummy variable with the dividend variable (i.e., the dividend response coefficient may vary depending on whether the company reports profits or losses). Analysis including this interactive term was undertaken, although none of the coefficients for this variable were statistically significant, and there was virtually no impact on the other regression coefficients or on the explanatory power of the models. Consequently, results are reported for models excluding this interactive term.

${ }^{3}$ An alternative specification of the model would be to adjust ni by deducting $d v$ when $\mathrm{dv}$ is included in the model, thus separating retained and distributed earnings. However, the chosen specification, which follows Fama and French (1998) and Rees (1999), allows for a direct test of the incremental value relevance of dividends. It should be noted that the choice between these two specifications has no impact on the other regression coefficients or on the explanatory power of the model.

${ }^{4}$ From the sample of 12,683 financial firm/years, 1,995 observations were excluded due to missing share price data, 5 due to share price being negative or zero, 18 due to missing book value of shareholders equity, 91 due to book value of shareholders equity being negative or zero, 523 due to missing ordinary dividend data, 3 due to incorrect dividend data (negative), 156 due to financial year being below 350 days, and 192 due to financial year exceeding 380 days.

${ }^{5}$ While this cutoff is necessarily somewhat arbitrary, countries with fewer observations did not have sufficient data to allow analysis at the industry level. The cutoff left us with a sample still exhibiting considerable heterogeneity, with two stakeholder, two shareholder, and two intermediate economies.

${ }^{6}$ For each country separately, the top and bottom one percent of observations for pr/eq and ni/eq, as well as the top one percent of dv/eq variables were deleted. (Due to too many ties (at zero), it was not possible to trim the bottom one percent of dv/eq). D and D.ni/eq were not trimmed, as these variables were derived from ni/eq, which had already been trimmed). As a robustness check, the analysis was re-estimated with trimming at the two percent level. This had no substantive impact on the core descriptive statistics, or on the regression coefficients. Significance levels were generally marginally lower due to the smaller sample size, although the conclusions were not altered. The analysis has also been undertaken using robust rank regression, which is insensitive to outliers.

${ }^{7}$ Prior evidence (e.g., Barth et al., 1992) indicates that the results are not sensitive to the choice between year end or disclosure date share prices.

${ }^{8}$ For the sake of brevity, the price to earnings ratio and the dividend yield ratios are not reported in the descriptive statistics as neither are used in the estimated models.

${ }^{9}$ To test the sensitivity of our results to alternative estimation procedures, all regressions were reestimated using non-parametric rank regressions, and, where feasible, annual regressions were estimated and the Fama-MacBeth (1973) approach used to estimate mean coefficients and confidence intervals. Where robust regressions indicated that either the sign or the statistical significance of the pooled OLS results was unreliable, the regression coefficient is reported in italics. 